\author{
Multidisciplinary \\ SCIENTIFIC JOURNAL OF \\ MARITIME RESEARCH
}

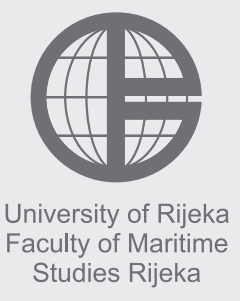

\author{
Multidisciplinarni \\ znanstveni časopis \\ POMORSTVO
}

\title{
Maritime spatial planning in Croatia - necessity or opportunity for balanced development
}

\author{
Mirjana Kovačić, Astrid Zekić, Biserka Rukavina \\ University of Rijeka, Faculty of Maritime Studies Rijeka, Studentska 2, 51000 Rijeka, Croatia, e-mail: biserka@pfri.hr
}

\section{ABSTRACT}

Understanding the complete human influence on maritime space has the central position in the planning process. Maritime spatial planning logically connects on integral planning of coastal area. Applying integral management on coastal and maritime area, together with the establishment of the process of maritime spatial planning makes the coupling regarding managing of the resources; all that is directed to the existence of sustainable development. Maritime spatial planning (MSP) is the process of analyzing and separating spatial and temporal divisions of human activities in the maritime area. Croatia, even though it is extremely maritime country, has not yet established complete legal framework for setting up MSP. This paper analyzes European legal framework for implementation of MSP process in Croatia. It provides the overview of the accomplishments achieved until today, as well as achievements of the Republic of Croatia during establishing legal and institutional framework for establishment and implementation of maritime spatial planning. The overview of application of MSP in European practice is specially presented.

The purpose of the paper is to analyze the growing needs for maritime space and the manners of amortization of its unorganized use. The goal of this paper is to point on the importance of adopting legal regulations regarding MSP and their practical application. Efficient management and protection of natural resources is specially emphasized, all for the purpose of reducing conflicts in maritime areas.
\end{abstract}

\section{ARTICLE INFO}

Review article

Received 23 May 2016

Accepted 15 June 2016

Key words:

Maritime spatial planning

Legal framework

Directive 2014/89/EU

Croatia

\section{Introduction}

Seas and oceans are the greatest source of biodiversity and their key functions are: climate regulation, prevention of erosion, absorption of carbon dioxide, accumulation and distribution of solar energy, maintenance of biological control. Therefore, there occurs the need for protection of that important inheritance.

Since there are greater conflicts present between different users of this area, this requires joint approach and methodology in order to establish the balance between maritime resources and their users. Maritime spatial planning is recognized as the process of managing maritime area that brings significant advantages. Directive 2014/89/ EU of the European Parliament and of the Council establishing framework for maritime spatial planning, defines maritime spatial planning as multidisciplinary instrument for easier implementation of eco-system approach, all in order to support rational use of maritime resources, harmonize people's present activities, reduce the impact on maritime environment to a minimum and ensure the resistance of coastal and maritime areas to climate changes [2].
Planning context is a dynamical process influenced by new technological knowledges. Social, economic and political conditions change through time. Constant monitoring and evaluation of maritime spatial planning contributes to their implementation and more efficient management of maritime resources.

European coastal states have already begun with the maritime spatial planning process regarding the area of their own competence. Today, establishing more rational organization of maritime space is not a privilege, but necessity. There exists a try to integrate economic exploitation and social benefits together with the obligation of protecting biological diversity of maritime environment.

Since Croatia is extremely maritime country, it is very important to establish legal framework for MSP.

\section{European legal framework for maritime spatial planning}

More intensive demand for maritime space for different needs, and at the same time, the need for preservation of eco-system and biological diversity, has encouraged 
European Union to adopt Directive 2014/89/EU establishing of legal framework for maritime spatial planning for the purpose of promoting sustainable development of maritime economic systems, sustainable development of maritime areas and sustainable use of maritime resources [2]. Environmental design provides the prerequisites for advancement of economic, social natural, cultural and ecological starting points for sustainable development in certain space.

Within integrated maritime policy of European Union, such framework provides to Member States the establishment and implementation of spatial planning of maritime area for the purpose of contributing to the goals defined by this Directive, taking in consideration land - sea interactions, as well as enhanced cross - border cooperation.

Scope of its application is defined by Article 2 of Directive 2014/89/EU where it is said that the Directive is applied on marine waters of Member States, and they do not refer to coastal waters or their parts that are encompassed by spatial planning on land, whilst Directive does not provide the definition of marine waters, but makes the reference to Directive 2008/56/EZ of the European Parliament and of the Council establishing a framework for community action in the field of marine environmental policy [3]. In reality, this means that Directive 2014/89/EU encompasses the space inside the borders of marine waters, but not the space that encompasses district, municipal and city spatial and town - planning schemes.

Spatial planning of maritime area represents the process in which competent state's bodies analyze, define and organize spatial and time division of relevant and existing and future activities, as well as the manners of using maritime area in its marine waters. Even though Directive 2014/98/ EU mentions possible activities and manners of using maritime area, Member States have the liberty of taking actions. According to Article 8 of the Directive 2014/89/EU, among the activities that may be encompassed by spatial plans of maritime area are: aquaculture, fishing, installations and infrastructures for the exploration, exploitation and extraction of oil, of gas and other energy resources, maritime transport routes and traffic flows, military training area, nature conservation sites, raw material extraction areas, scientific research, laying of cables and oil pipelines, tourism and underwater cultural heritage [2].

Directive prescribes minimal requirements for spatial planning of maritime area. According to the Article 6 of Directive 2014/89/EU, Member States must take into account land-sea interactions, environmental, economic and social aspects, as well as safety aspects. The obligation of the Member State is to promote coherence between maritime spatial planning and the resulting plan or plans and other processes, such as integrated coastal management and encourage the compatibility of maritime spatial planning and plans with other processes such as integrated management of coastal area.

For efficient maritime spatial planning, it is necessary to ensure public participation and interested partners, as well as to use the best available data. Participation of partners and public is regulated by the Article 9 of Directive 2014/89/EU. General obligation to establish the procedure of participation of public and interested copartners while making maritime spatial plans is imposed to the Member States.

Having in mind that interventions in maritime area of one state may have cross - border influence on other states, the cooperation between the Member States is necessary, as well as cooperation with the third countries.

In order to implement Directive 2014/89/EU, Member State defines one or more authorized bodies, and the data concerning previously mentioned bodies are delivered to the Commission [2].

Directive 2014/89/EU prescribes the obligation of the Member State to review the spatial plans of maritime area with the final deadline of ten years. It is clear from the text of the Directive that Member States may prescribe even shorter deadline if they find it reasonable and justified.

\section{Analysis of applying MSP in EU}

Establishment of maritime spatial planning has marked the last decade in many coastal countries of Western Europe. Several maritime spatial plans have already been brought, some of them have already been implemented and revised.

\subsection{Examples of European experience}

Maritime spatial planning contributes to the promotion of sustainable development and growth of maritime and coastal economy, as well as to use of maritime and coastal resources. The form and the content of maritime spatial plans are left to be determined by Member States themselves. The biggest breakthrough regarding implementation of maritime spatial planning has been done in Belgium and Norway.

Belgium started the establishment of maritime spatial planning in 2003 by graduate zoning of main industrial areas (zones), especially wind energy farming at sea, and it continues to mark the protected areas. Planning is being developed on the precaution principles, according to the following scripts:

- The relaxed sea, focusing on well - being;

- The natural sea, focusing on ecology and landscape;

- The rich sea, focusing on economy;

- The playful sea, focusing both on well - being, ecology and landscape;

- The mobile sea, focusing on both ecology and landscape, and economy and;

- The sailing sea, focusing on both economy and well being [5].

On 20 March 2014, Belgium approved a new maritime spatial plan by Royal Decree. The Plan encompasses six years period and it is regularly reviewed. 
Norway applies three maritime spatial plans; the plan for Barents Sea which is completed and revised, Plan for Norwegian Sea which is completed, and Plan for North Sea that is currently being done. The biggest challenge is to make the reconciliation between the fisheries and growing maritime traffic and activities related to exploitation of hydrocarbons. The planning process for Barents Sea started in 2002 under the supervision of Ministry of Climate and Environment for the purpose of establishing complete ecosystem management of activities and lowering pressures on environment. Accomplishing set goals is measured by coordinated and systematic monitoring of maritime environment. The Plan was revised in 2010 and accepted by Parliament in March 2011. Next revision of the Plan is scheduled for 2020. Management plan for Norwegian Sea had been developing from 2007 and 2009 and was accepted by Parliament in May 2009. Plan defines ecological areas whilst the main criterion refers to biological diversity or biological production, which defines the selection of measures regarding area management. Secondary criteria were: economic importance, social and cultural significance. The Plan is specific because it includes the development of future activities, but also external pressures on maritime environment such as cross - border pollutions, climate changes and invasive species. The plan was revised in 2014. Complete revision of the Plan is predicted for 2025. Continued cooperation with Russia on management and implementation of decisions is especially important: without such cooperation, the plan would lose some of its potential merit [9].

Germany has expanded its Land Use Planning Act, and by doing so, it also expanded federal authorities for spatial planning to exclusive economic zone [11]. For German exclusive economic zone (EEZ), MSP has mainly been adopted for the purpose of designating Natura 2000 sites under the EU Birds Directive (79/409/ EEC) and EU Habitats Directive (92/43 EEC) and preferential areas for offshore wind energy farming but not for fisheries despite its high economic importance and long cultural tradition [6]. Regulatory plans for the area of North Sea and Baltic are in force. National and international monitoring is being done for the area of North Sea.

Agency for Marine and Water Management (SwAM) is responsible for managing and coordinating maritime spatial plans in Sweden [21]. Ensuring the strategic study regarding impact on the environment is also one of its responsibilities, as well as analysis of social - economic impacts of the implementation. Maritime spatial planning is done in phases within the set timeframe:

- Phase 1 - estimating current situation and defining directives, 2013-2016 (in progress);

- Phase 2 - preparing drafts of maritime spatial plans and regulations, 2015-2017;

- Phase 3 - consultations regarding maritime spatial plans drafts, influences and regulations, 2017-2018;

- Phase 4 - maritime spatial plans proposals and regulations are delivered to Government, 2018-2019.
New maritime spatial plans proposals will be prepared according to the need, or at least every eight years.

In Poland, maritime spatial planning is regulated by Act on Maritime Areas of Poland and Maritime Administration [21]. The first maritime spatial plan is prepared for the area of the Gulf of Gdansk in cooperation with the Maritime Office in Gdynia and Maritime Institute in Gdansk. Over 50 central, regional and local partners were consulted in order to resolve existing spatial conflicts and to improve the state of the natural ecosystem and the economy. A draft plan was completed in September 2008.

By establishing national legislation in 2009 regarding sea and coastal area, there were created the preconditions for maritime spatial planning in Great Britain, despite the efforts that started seven years earlier [21]. The Marine and Coastal Access Act establishes Marine Management Organization (MMO) with the purpose of establishing maritime spatial plans for all the waters in Great Britain. Maritime spatial plans refer to sea and coastal areas. They are brought for the period of 20 years, starting from the day of their bringing. But, there are possible adjustments. Efficiency of marine spatial plans is revised every three years and the Report is presented to the Parliament. After that, a decision will be made whether or not the plan needs to be amended or replaced.

Spanish Act on Protection of the Marine Environment from 2010 transfers Directive 2014/98/EU and sets general principles and procedure for establishing MSP [21]. Even though initiatives such as marine protected area, NATURA 2000, renewable energy sources have started, Spain has not developed integrated MSP process.

There are also examples of common establishment of maritime spatial planning. One of them is Trilateral Wadden Sea Plan that includes Denmark, Germany and the Netherlands. In the focus of the plan there are: landscape and culture, sea water and sediment, salt marshes, tidal area, beaches and dunes, estuaries, offshore areas, rural areas, birds and marine mammals.

It is clear that the need for using maritime area is strong. Described initiatives of maritime spatial planning are some of the best examples that are available today.

\subsection{Analysis of the legal framework of maritime spatial planning in Croatia}

More and more significant geostrategic position of Adriatic Sea increases maritime traffic in that area. Economic exploitation of sea resources through fishery, mariculture and tourism makes significant economic branches. At the same time, Adriatic Sea is sensitive maritime area that requires proper management with the purpose of sustainable development and establishment of continuous monitoring from all the countries that exit to Adriatic Sea. In that sense, a special attention needs to be paid to use and preservation of Adriatic Sea.

Especially valuable parts of human environment having special protection - sea and sea coast - have been defined for the first time by Act on Physical Planning and Use 
of Building Land from 1973 [14]. The issue of using coast and maritime resources is still in the focus of interest of creators of legal norms, therefore, Act on Physical Planning and Space Defining from 1980 defines that protected coastal zone is set by municipal spatial plan, depending on its purpose, configuration and other characteristics of the field and construction of the space [15]. Physical Planning Act from 1994 did not recognize Croatian coastal area as the space that has significant development potential, and this omission is being removed by its revision in 2004. Act on Amendments and Supplements of Physical Planning Act from 2004 defines the necessity to control construction works on sea shore, it also determines a protected coastal area consisting of all islands, a $1000 \mathrm{~m}$ wide mainland and a $300 \mathrm{~m}$ wide marine belt measured from the coastline. As additional legal source, there has been brought a special Regulation on Management and Protection of the Protected Coastal Marine Areas [12]. Act on Physical Planning and Building was brought in 2007, it prescribes the obligation of making urban plans and stops further spreading of building sites on the coast [17].

In order to ensure needed protection of coastal area and maritime resources based on integrated approach, the Republic of Croatia in 2012 confirms Protocol on Integrated Coastal Zone Management regarding Mediterranean area, by which it accepts the international obligation of spatial planning of coastal area, protection of environment and nature, protection of cultural heritage and policy of sustainable development of coastal economy [19]. During direct membership of Croatia in European Union, in 2013 there has been established National infrastructure of spatial plans that provides efficient collecting, managing, exchange and use of spatial data.

Spatial planning system in the Republic of Croatia was established by Physical Planning Act that came into the force on $1^{\text {st }}$ January 2014. According to the Physical Planning Act, spatial planning is based on integrated approach principle, regarding planning and managing the space that encompasses coast and the sea and their mutual interaction [18]. Spatial planning legislation in the Republic of Croatia is not a subject matter of special legislature, but it is integrated in Physical Planning Act. Since Physical Planning Act has not entirely taken solutions contained in Directive 2014/89/EU regarding establishing framework for spatial planning of maritime area, there has been made an approach to drafting Act on Amendments and Supplements of Physical Planning Act, that is in the procedure of its bringing.

For the purpose of complete harmonization of Physical Planning Act and Directive 2014/89/EU establishing framework for maritime spatial planning, it is necessary to define the concepts of spatial planning of the sea and maritime area and expand the application of Physical Planning Act in the Ecological and Fisheries Protection Zone and continental shelf of the Republic of Croatia.

Spatial application of Directive 2014/89/EU is determined indirectly, by defining the concept of sea and sea waters, by which it fulfills the condition prescribed by the regulation of the Article 2 paragraph 1 and Article 3 paragraph 4 of Directive 2014/89/EU. Croatian sea waters are classified in the sea region of Mediterranean Sea, sub region Adriatic Sea.

Besides spatial grasp, the supplements of the Act should directly prescribe goals and principles of spatial planning of maritime area as they are defined by Directive 2014/89/EU; that is because on the bases of them, there will be created individual spatial plans that encompass the sea.

Article 49 a) of the draft of Act on Amendments and Supplements of Physical Planning Act introduces into the Croatian system state's obligation of spatial planning of the sea, as well as such obligation of regional and municipal self - government. In order to make the difference from the present legislation, it also encompasses the planning of ZERP (Ecological and Fisheries Protection Zone (EFPZ)) and continental shelf of the Republic of Croatia, and it prescribes spatial plans for doing so. When compared to the present system of spatial plans (state's spatial plan, district spatial plans that encompass sea and city and municipal spatial plans), new spatial plans are introduced having the special purpose: Spatial Plan for Ecological and Fisheries Protection Zone (EFPZ) and Spatial Plan for Continental Shelf of the Republic of Croatia [18].Croatian Institute for Spatial Development and county offices for spatial development are considered responsible for implementation of Physical Planning Act, meaning in its part that refers to spatial planning of maritime area.

Cooperation of the Republic of Croatia with other EU Member States regarding the area of maritime spatial planning in the sub region of Adriatic Sea has special importance, as well as cooperation with other states that are not EU Member States, all referring to the maritime spatial planning in the sub region of Adriatic Sea. Regulation of the Article 49 d) Paragraph 2 limits the legal reach of the cooperation in a manner that cooperation does not have the effect on sovereign rights and jurisdiction of the Republic of Croatia that come out of national and international law. Regulation of the Paragraph 3 of the same Article prescribes that the manner of the cooperation is defined by the spatial plan decision [18].

The shortest possible prescribed time limit for duration of public access to the proposal of spatial plan is 30 days. By this, Croatian legislation is being harmonized with the demands prescribed by Aarhus Convention and relevant legislation rules of European Union.

By accepting acquis communautaire of European Union, the Republic of Croatia has taken the obligation of making the strategy regarding the protection of maritime environment, and by ratification of Protocol on Integrated Coastal Zone Management in the Mediterranean, it has taken the obligation to make national strategy of integral coastal zone management. In order to consolidate this two above mentioned demands, the Government of the Republic of Croatia in October 2014 brought the Regulation on Creation and Implementation of Strategy on Maritime Environment and Coastal Zone Management which gener- 
ally defines bodies and responsibilities for the preparation of the Strategy. The need for consolidated Strategy has been derived from overlapping of spatial coverage, mutual dependence of coastal development and current situation of maritime environment, meaning the influence of the sea on coastal development. Implementation of the Strategy is in progress.

Many projects and initiatives are being implemented on the area for which the Republic of Croatia has interest, among them Project ADRIPLAN has a great importance. Collected data that are related to the condition of the sea within the area of North and South Adriatic and Ionian Sea, as well as the data regarding pressures on the maritime area, will serve as the initial point for bringing management plans and decisions related to management of this area. The ultimate goal is to achieve good condition of maritime environment, meaning sustainable use of resources [8].

By bringing Act on Amendments to the Physical Planning Act, Croatia will fulfill one of the important premises of successful establishment and implementation of maritime spatial planning in practice, and that is the existence of adequate legal and institutional framework. The final deadline for bringing maritime spatial plans is $31^{\text {st }}$ December 2021, having in mind that Directive calls the Member States to bring such plans as earlier as possible.

\section{Maritime spatial planning and integrated approach}

While in the past industrialization of ocean use has been the most prominent in the fisheries, maritime transport, communications, oil and gas exploitation, marine recreation and coastal engineering, it is particularly the rise of new uses, such as renewable energy and nature conservation initiatives, which has made decision - makers recognize the need to develop and implement an integrated and more rational use of ocean space [4]. Integral planning is necessary because maritime space occurs in its wholeness as development resource while at the same time, related human activities also have strong influence. Analogues to land-use planning in the terrestrial environment, MSP aims to identify a balance between social and economic demands for development, while protecting the health and resilience of ecosystems [1].

Integral planning is a complex issue and the composing part of integral development. Planning occurs in it as the method that serves for consciously going forward and directs the development towards the chosen goal. In such manner, human activities of certain environment become efficient and rational. Integral planning has the meaning of integration of existing planning systems, such as economic, spatial and social planning, into the unique system [20]. If the development is done spontaneously, then the economic concentrations of nodal mode are developed on the coastal line, consisting the same or similar economic or functional structure, which makes them mutually competitive.
Planning of using maritime space and interventions in it must be based on the structural analysis of all constant and variable components that define the space and today have the effect in it, and all the others that may be foreseen in the future. Managing and ruling the space in general, especially with maritime and costal space, requires legislative and institutional solutions that will serve for the development of the space and organization. Maritime spatial plans and strategies of integrated management of coastal area must be mutually coordinated, they must ensure efficient cross - border cooperation between the Member States and between national bodies and copartners of relevant sector policies, they must define cross border effects of maritime spatial plans and strategies of integrated management of coastal area on sea waters and coastal areas [20].

Generally, issues related to maritime spatial area are very complex and must be solved on all the levels, by taking in consideration mutual relations between the elements. All social and interested structures must be involved in the problem solving issues of maritime space from the early beginning, and citizens have especially important role [8]. Respecting spatial component is very important, even in early preparatory stage, in order to timely make the perception of all aspects and possible effects of spatial grasps and avoid the conflicts [7].

Above mentioned requires that for every new grasp, there have to be defined the deviations from the set development goals and possible consequences. However, it may be expected that reasonable decision making will require compromises to the detriment of one or other partner. It is especially important to understand that maritime system is dynamic and that there is no territorial border. Therefore, it needs to be observed in the wider context.

\section{Conclusion}

Different activities, whether they are economic, cultural, ecological or social, cause pressures on maritime ecosystem, therefore, there occurs the need for new approach of using maritime area. Maritime spatial planning offers new frame regarding managing activities at sea with the goals that harmonize social and ecological requirements with ecological functions.

Practice and interest for maritime spatial planning in European coastal states lately experience the significant growth. By establishing the process of maritime spatial planning, there is a try to harmonize spatial influence of different users in order to direct their activities to the protection of the sea. Establishing maritime spatial plans makes the significant step out in applying eco-system sea environment management.

Croatia is in the process of bringing Act on Amendments to the Physical Planning Act, and by its adoption, Directive 2014/89/EU will be entirely implemented. Having in mind that the deadline for implementation of Directive $2014 / 89 /$ EU in the national legal system is $18^{\text {th }}$ September 2016, it is expected that Croatia will fulfill its obligation 
at due time. Croatian proactive policy regarding establishment of maritime spatial planning is recognized in endorsing Protocol on Integrated Coastal Zone Management and initiating the procedure of bringing Strategy on Maritime Environment and Coastal Zone Management of the Republic of Croatia.

Croatia has the unique opportunity to make legal framework that will establish maritime spatial planning, all by accepting the European practice of coastal countries. Existing conflicts, interests and issues will definitely not be resolved, but MSP as transparent process that provides participation of interest groups on different levels, will contribute to decrease of conflicts and increased protection of maritime and coastal resources.

\section{References}

[1] Baldwin, K., Schill, S., Zenny, N., Blake, D.: Developing Ecosystem-Based Information for Marine Spatial Planning on the Pedro Bank, Jamaica, Proceedings of the $67^{\text {th }}$ Gulf and Caribbean Fisheries Institute November 3-7, 2014, Christ Church, Barbados, pp. 27-36.

[2] Direktiva 2014/89/EU Europskog parlamenta i Vijeća od 23. srpnja 2014. o uspostavi okvira za prostorno planiranje morskog područja, SL L 257, 28.8.2014.

[3] Direktiva 2008/56/EZ o uspostavi okvira za djelovanje Zajednice u području politike morskog okoliša, SL L 164, 25.6.2008.

[4] Douvere, F., Ehler, C.: Ecosystem-Based Marine Spatial Management: An Evolving Paradigm for the Management of Coastal and Marine Places, Ocean Yearbook 23, 2009, pp. 1-26.

[5] Douvere, F., Maes F., Vanhulle, A, Schrijvers, J.: The role of marine spatial planning in sea use management: The Belgian case, Marine Policy, Vol. 31, 2007, pp. 182-191.

[6] Fock, H. O.: Fisheries in the context of marine spatial planning: Defining principal areas for fisheries in the German EEZ, Marine Policy, Volume 32, Issue 4, July 2008, pp. 728-739.
[7] Kovačić, M., Luković, T.: Prostorne značajke planiranja i izgradnje luka nautičkog turizma, Geoadria, Vol. 12, No. 2, 2007, pp. 131-147.

[8] Kovačić, M., Schiozzi, D., Zekić, A.: The Experiences and Dilemmas in implementing the Marine Spatial Planning in Integrated Coastal Zone Management, 35 ${ }^{\text {th }}$ International Conference on Organizational Science Development. "Sustainable Organization”. 35 (2016); Portorož, pp. 398-404. CD Proceedings.

[9] Olsen, E., Gjøsæter, H., Røttingen, I., Dommasnes, A., Fossum, P., Sandberg, P.: The Norwegian ecosystem-based management plan for the Barents Sea, ICES Journal of Marine Science, Vol. 64, No. 4, 2007, pp. 599-602.

[10] Prijedlog Zakona o izmjenama i dopunama Zakona o prostornom uređenju, https://vlada.gov.hr.

[11] Runko Luttenberger L.: Izazovi morskog prostornog planiranja, III. savjetovanje o morskoj tehnologiji in memoriam akademiku Zlatku Winkleru, Rijeka, 2009, Zbornik radova, HAZU, pp. 84-93.

[12] Uredba o uređenju i zaštiti zaštićenog obalnog područja mora, NN 128/04.

[13] Uredba o izradi i provedbi Strategije upravljanja morskim okolišem i obalnim područjem Republike Hrvatske, NN $112 / 14$.

[14] Zakon o prostornom uređenju i korištenju građevinskog zemljišta, NN 14/73.

[15] Zakonom o prostornom planiranju i uređivanju prostora, NN 54/80, 16/86, 18/89, 61/91, 59/93.

[16] Zakonom o prostornom uređenju, NN 30/94, 68/98, 61/00, $32 / 02$.

[17] Zakon o prostornom uređenju i gradnji, NN 76/07, 38/09.

[18] Zakon o prostornom uređenju, NN 153/13.

[19] Zakon o potvrđivanju Protokola o integralnom upravljanju obalnim područjem Sredozemlja, NN 8/12.

[20] Zekić, A., Luttenberger, A.: Doprinos morskog prostornog planiranja zaštiti morskog okoliša, Pomorski zbornik, Posebno izdanje, No. 1, 2016, pp. 283-296.

[21] www.unesco-ioc-marinesp.be. 